\title{
EDITORIAL
}

\section{Criminology, deviant behaviour, and mental disorder}

The role played by illness in the genesis of antisocial behaviour is a difficult topic, but a rewarding one. It forces the psychiatrist to examine critically the meaning of the term mental disorder and to consider the social implications of applying this label to an individual.

It is widely accepted that some seriously crippling mental syndromes are properly called illnesses, and that in some cases these illnesses may be the cause of antisocial conduct. A classic example is the persecutory syndrome of the hallucinated and deluded paranoid schizophrenic. Indeed, it was a murder committed in 1843 by the deluded McNaghten, to draw attention to his imagined wrongs, that led to the formulation by the famous judges' rules that were to govern for more than a hundred years the English law on criminal responsibility (Walker, 1968). In the days when psychiatric evidence at criminal trials was limited to such extreme cases of psychosis, one might suppose there would have been little scope for controversy, but dramatic confrontations between lawyers and psychiatrists were common-place. This was because the courts used not to be concerned with whether the accused was mentally ill, but wanted to know whether he knew what he was doing when he committed the crime. Traditionally, it has been the custom for lawyers to argue that only exceptionally should a criminal avoid responsibility on grounds of mental illness, whereas psychiatrists have wanted a larger proportion of criminals to be recognized as sick people needing treatment instead of punishment. Law reform, inspired by humanitarian ideals, has favoured the latter view. Nowhere is this more evident than in the handling of juvenile delinquency. This task is now officially designated as the business of the social and medical services rather than that of the penal system.

In recent years, the trend towards a non-punitive approach to criminals has sustained a new challenge from both lawyers and sociologists, this time on the grounds that an offender's interests are poorly served by classifying him as 'a case for treatment'. The medical label may be used to justify supervision and control for an indefinite period, whereas the offender himself would much prefer to receive a well-defined punishment of specified duration. Law-breakers dealt with under the penal system enjoy the built-in protection of the sentencing process, which ensures that an offender does not suffer more than is justified by the seriousness of the crimes for which he is convicted. Some forensic psychiatrists in America take this very seriously, arguing that all persons, whatever their mental health, should be tried and held responsible for their actions, and that any sanctions invoked against offenders should be guided by the criminal code and not by a psychiatrist's opinion (Szasz, 1963).

Sociologists have criticized the use of psychiatric labels in an even more fundamental way, questioning the validity of concepts of illness, arguing that what the psychiatrist calls sickness is merely behaviour which deviates from a conventional social norm. Standards of acceptable behaviour vary widely according to social class and cultural expectations. The social setting determines which persons are considered to be sick. The fate of the individual deviant, the way he is treated by family and friends, and his own subsequent behaviour are governed by social interactions that have nothing to do with any internal disease process. This view is supported by evidence that the picture of chronic psychotic illness can be dramatically affected by incarceration in a restrictive institution (Goffman, 1961). It has also been demonstrated that the level of disturbance justifying hospital admission has as much to do with the attitude of the relatives as the behaviour of the prospective patient (Scheff, 1966). Some modern sociologists view the system of psychiatric diagnosis as a subtle form of covert control by the orthodox establishment. By defining inconvenient behaviour as sickness, they help to suppress individuals who step out of line. The most blatant example in recent 
limes is the Russian practice of committing to hospital on psychiatric grounds persons with deviant political views.

These controversies give added importance to distinctions between mental symptoms caused by internal organic factors, and syndromes which are a reaction to social circumstances and pressures. One distinguished modern philosopher (Flew, 1973) considers the medical approach to mentally disturbed criminals largely illogical and inappropriate, but he makes an exception in the case of syndromes of organic origin, and agrees that these are properly dealt with medically rather than by penal sanctions. The difficulty is, of course, that antisocial behaviour, in the case of epileptics and mental subnormals for instance, is so often due to a combination of organic impairment and unfavourable social circumstances. The suspicion that psychiatric syndromes long believed to have primarily genetic and organic causes may be due to social interaction has received a great impetus in recent years from psychiatrists themselves. Some enthusiastic exponents of the psychodynamic explanation of psychosis (Laing and Estersen, 1964) have put forward clinical evidence that ambiguous and faulty upbringing-for instance, the famous 'double bind' situations-may force the scapegoat member of a family to defend himself with the kind of reactions psychiatrists attribute to a schizophrenic disease process. Such writers are enthusiastically followed and quoted by the new school of sociological criminology which asserts that deviance is a matter of social conflict rather than intrapsychic conflict.

One of the major emphases of this new criminology is the study of the definers of deviants (Taylor, 1973). Who formulates the criminal law, who decides which are the most serious offences, and how are priorities worked out for the pursuit and prosecution of deviants? For instance, how does it come about that the use of cannabis and other euphoriant drugs comes to be defined as a serious social problem and is subject to heavy penalties, while the larger problem of alcoholism receives comparatively little attention from either news media or legislators? For what reason, and in whose interest, do certain legislations seek to control the use of pornography or the practice of homosexuality? The questions have a left-wing political flavour. It is suggested that the dominant section of society responsible for law making has an interest in preserving the status quo because their privileges depend upon a continuance of the present economic system. The youthful drug culture encourages contempt for the work ethic, sexual freedom threatens family discipline and so indirectly undermines the stability of the labour force (Altman, 1972).

The traditional psychiatric approach, which tends to equate deviance with sickness, is most open to question when dealing with behaviours which, although considered reprehensible or abnormal by respectable society, nevertheless enjoy the support and approval of substantial minority groups. The psychoanalytic view, which interprets homosexual behaviour as a symptom of neurosis, collides head on with the vocal claims of the 'homophile' movements, who assert that their members are in no way sick because their sexual preferences don't happen to be shared by the majority. Men who would he inevitably diagnosed as psychopaths by some middle-class psychiatrists, on account of their impulsively hedonistic conduct and seemingly callous neglect of social responsibilities, may be looked upon as very ordinary by their own fraternity. According to the predilections of the observer, the same man may be regarded as a heroic freedom fighter, a criminal terrorist, or an aggressive psychopath.

To a very large extent antisocial personalities appear to be the product of faulty social learning. Many surveys have shown that erratic upbringing in overcrowded, quarrelsome, neglectful, impoverished homes, often punctuated by periods in childrens' institutions, tends to produce an undisciplined, aggressive, antisocial adult personality. In the male sex, at least, the syndrome is likely to include criminal convictions and a diagnosis of psychopathy. Whether this outcome is called an illness or not is a matter of semantics. From a practical standpoint the more important question is what to do about it. In most cases the psychiatrist can do very little to intervene. The remedy, if any, would seem to lie more in the domain of social policy, in the battle against poverty, and in the provision of special attention to the care and education of deprived children. There is some truth in the sociologists' criticism that too much attention to the personal peculiarities or defects of the 
individual deviant may divert attention from the economic and social pressures that are the root causes.

In spite of the importance of social factors in deviant behaviour, the medical approach still has a significant part to play, and the investigation of individual pathology among the members of deviant groups continues to lead to results of practical and theoretical importance. The discovery of a significant excess of XYY males among the inmates of special hospitals, the EEG anomalies found in some aggressive prisoners, and the evidence that psychopathic personality may be associated with sluggish cardiovascular response to stress, are just three examples. Each one of these findings has served to open up a new avenue for psychiatric research, none of which has as yet been fully exploited.

D. J. WEST

\section{REFERENCES}

Altman, D. (1972). Homosexual Oppression and Liberation. Angus and Robertson: Sydney.

Flew, A. (1973). Crime or Disease? Macmillan: London. Goffman, E. (1961). Asylums. Doubleday: New York.

Laing, R. D., and Esterson, A. (1964). Sanity, Madness and the Family. Vol. 1. Tavistock: London.
Scheff, T. J. (1966). Being Mentally IIl: a sociological theory. Aldine: Chicago.

Szasz, T. S. (1963). Law, Liberiy, and Psychiatry. Macmillan: New York.

Taylor, L. (1973). Deviance and Society. Nelson: London.

Walker, N. (1968). Crime and Insanity in England. Vol. 1. Edinburgh University Press: Edinburgh. 